\title{
Structural analysis, metamorphism, and geochemistry of the Archean granitoids-greenstones of the Sukumaland Greenstone Belt around Geita Hills, Northern Tanzania
}

\author{
Nelson Boniface ${ }^{1^{*}}$, Abdul H. Mruma ${ }^{1,2}$ \\ ${ }^{1}$ Department of Geology, University of Dar es Salaam, Dar es Salaam, Tanzania; \\ *Corresponding Author: nelson.boniface@udsm.ac.tz \\ ${ }^{2}$ Geological Survey of Tanzania, Dodoma, Tanzania
}

Received 1 July 2012; revised 10 August 2012; accepted 16 August 2012

\section{ABSTRACT}

Greenstone rocks, which include Banded Iron Formations (BIFs), tuffs, volcanic flows (basalt, andesite and rhyolite), and clastic sedimentary rocks (shale-mudstone, greywacke-sandstone and conglomerate), crop out around Geita Hills and are flanked by granites and granodiorites. BIFs and tuffs occupy larger area than other lithological units, which crop out as patches. Structural analysis indicates that layers of greenstone rocks are folded and display a regional fold axis with an attitude of $320^{\circ} 140^{\circ}$. Low-grade metamorphic mineral assemblages (actinoliteepidote-chlorite in basalts and muscoviteepidote-chlorite in granitoids) are common in these rocks; this indicates a regional metamorphism at greenschist facies. However, BIFs and basalts are locally metamorphosed to epidoteamphibolite and amphibolite facies. Basalts belong to the tholeiite series whereas granites, diorites and rhyolites belong to the calc-alkaline series. Chondrite normalized rare earth element pattern of basalt is flat and plot slightly below the average N-MORB values suggesting the enrichment of the light rare earth elements, which means that mantle magma source was an EMORB. Granitoids and rhyolites have strong affinities to the continental arc source magma displaying strong enrichments in the LREEs with $(\mathrm{La} / \mathrm{Sm})_{\mathrm{N}}$ values ranging between 2.53 and 3.95 in rhyolites and between 4.08 and 5.40 in granitoids. The granitoids are classified as the I-type synorogenic metaluminous granites and granodiorites. Geochemical signatures suggest that the Geita Hills basalts erupted at the en- riched mid ocean ridge setting of the back arc setting, and the granites, granodiorite and rhyolite formed in a volcanic arc setting particularly the continental arc.

Keywords: Granite-Greenstone; Greenschist Facies; Sukumaland Greenstone Belt; Archean

\section{INTRODUCTION}

Most of the world Archean provinces (4.0 - $2.5 \mathrm{Ga}$ ), which are popular for gold mineralization, are composed of granite-greenstone terranes associated with or without high-grade metamorphic provinces [1]. The terranes are characterized by discontinuous greenstone belts engulfed in a "sea" of granite and gneisses. The major granitegreenstone of the world occur in the Superior and Slave provinces in North America, in the Zimbabwe and Kaapvaal provinces in southern Africa and in the Yilgarn and Pilbara provinces of Western Australia [2]. The metamorphic grade of Archaean greenstone rocks ranges from greenschist to amphibolite facies [2]. Higher grades typically occur around the margins of greenstone belts, probably caused by intrusion of plutons [3]. Structural analysis of Archean greenstone belts shows that they are considerably complex; most successions have undergone two or three periods of major deformation and metamorphism [2] and the references therein.

In Tanzania, the Archean greestones, namely the Kavirondian and Nyanzian Supergroups or Lake Victoria Gold Fields (2820 - $2540 \mathrm{Ma}$ ) and the associated coeval high-grade Dodoman Supergroup (2680 Ma) occur in the Tanzania Craton [4-6], see Figure 1. The Sukumaland Greenstone Belt is part of the large Lake Victoria Gold Fields in which the banded iron formation, volcanic successions and "sea” of granites occur. In this work we 


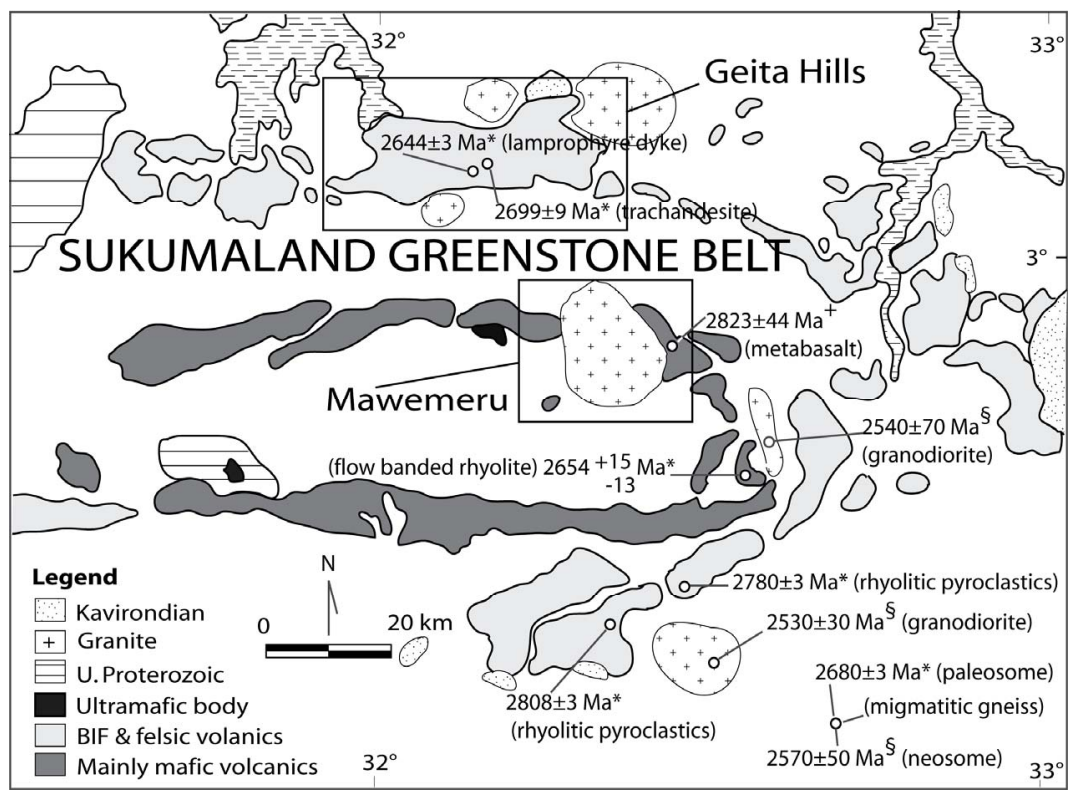

Figure 1. Geological map of the Sukumaland Greenstone Belt showing the location of Mawemeru and Geita Hills (modified from [7]). Geochronological data; *[5], ${ }^{+}[6],{ }^{\S}[8]$.

intend to characterize structural patterns in granitoidgreenstone sequences of Geita Hills, establish geochemical characteristics of granites and volcanic rocks for the purpose of deducing their tectonic settings, and to establish the distribution of different lithological units and their field relationship (stratigraphy).

\section{GEOLOGICAL SETTING}

Geita Hills are located in the Sukumaland Greenstone Belt in Geita Region. Stratigraphically the Sukumaland Greenstone Belt belongs to the Neoarchean Nyanzian Supergroup [7]. The belt is made up of two intermittently exposed arcs of metavolcanic and metasedimentary rocks surrounded by granitoid rocks (Figure 1). References [4, $7,9]$ reviewed the geological setting and lithostratigraphic subdivisions of the Sukumaland Greenstone Belt. These workers suggested that the inner arc of the Sukumaland Greenstone Belt, which consists of gabbro, pillow basalt and subordinate felsic lava flows and pyroclastics is a representative of the lower Nyanzian Supergroup subdivision. The upper Nyanzian subdivision, which crops out in the outer arc is predominantly composed of banded iron formation (BIF), felsic pyroclastic and lava flows and carbonaceous shales. The upper Nyanzian is overlain unconformably by the Kavirondian Supergroup, composed of coarse clastic metasediments [4]. This stratigraphic relationship is consistent with the general stratigraphic arrangement encountered in other greenstone belts of the world [10].

Numerous granitoids intrude and flank the Nyanzian greenstone belts [11]. Four generations of granitoids can be distinguished by their chemical and petrographic composition and by their tectonic location in relation to the greenstone belts. Synorogenic granodiorites and granites with subordinate intrusions of alaskites and microgranites are the most abundant plutonic rock types in the region [11]. The foliated synorogenic granitoids weather easily and occupy most of the low lands in the region. Less deformed, late orogenic high-K granites are the second most important magmatic rock type [12]. Only a few occurrences of non-foliated, post orogenic alkali-granitoids and syenites are known in the Sukumaland greenstone terrane [5].

The entire Nyanzian sequence has been metamorphosed to the greenschist facies and locally to the middle amphibolite facies in the thermal aureoles of large granitic intrusion [13]. Locally plutons have caused contact metamorphism to the amphibolite facies in the ironstones of Geita Hills and Metabasites of Mawemeru [14]. The state of deformation in the greenstone belt is variable with deformation intensity increasing near regional scale shear zones. Four discrete deformational episodes can be distinguished [7]: a poorly preserved early thrust and nappe tectonic phase associated with tectonic stacking was followed by episodes of tight to open upright folding along sub-horizontal axes. The latter was followed by an episode of tight to isoclinal folding with steeply plunging axes. The deformational history of the area was concluded by a post-Archean phase of steep normal and reverse faulting.

\section{METHODOLOGY}

Structural data, attitudes of bedding, shear planes, joint 
and fault planes, were acquired directly in the field from BIFs, tuffs, granitoids and clastic sedimentary rocks. The data were analysed using a simple program (sterionet) available freely on line.

Volcanic rock samples (3 basalts and 3 rhyolites) and granites (6 samples) from localities indicated in a geological map of Geita were selected for analysis of major elements. The samples were crushed with a steel jaw crusher and then powdered in an agate mill. A Philips PW 1400 X-ray fluorescence analyzer at Kiel University was used to determine major element concentrations on fused glass discs, which were prepared by mixing in a platinum crucible, $0.6 \mathrm{~g}$ of a sample powder with $3.6 \mathrm{~g}$ of $\mathrm{Li}_{2} \mathrm{~B}_{4} \mathrm{O}_{7}$. The mixture was then subjected to the OXIFLUX 5-stage burner. Trace elements were analysed from a few selected samples ( 1 basalt, 2 rhyolites and 3 granites,) using an upgraded Plasmaquad PQ1 ICP-MS, also at Kiel University by dissolving the samples using the lithium borate fusion procedure and measuring after the method described by [15]. Data quality, precision and accuracy, was ensured by analyzing international reference materials, blanks and sample duplicates (reproducebility of the international standard BHVO-2 is given in Tables 1 and 2).

\section{RESULTS AND DISCUSSION}

\subsection{Petrography and Structures}

Lithological units around Geita Hills include grani- toids, which surround BIFs and tuffs (the major lithological units of the area). The NE-SW dykes (gabbroic to granitic in composition) are also common in the area. Volcanic rocks of basaltic to rhyolitic compositions and clastic sedimentary units occur as patches (Figure 2). The basaltic volcanic rocks are locally metamorphosed to amphibolite facies. Thrusts, sheath folds, and lineations are common in BIF and volcanic sequences at Geita Hills manifesting complex deformational history of which [16] proposed as a result of a single deformation. Simplified stratigraphy of the Archean greenstone sequences of Geita Hills shows from the bottom to the top: volcanic flows (basalt, andesite and ryholite), pyroclastic volcanics (tuff), chemical sediments (BIF and chert layers), and clastic sediments (shale-mudstone, greywacke-sandstone, and conglomerate). Structural and petrographic details about BIFs, tuffs, volcanic rocks, clastic sedimentary rocks and granitoids are discussed below.

\subsubsection{Banded Iron Formation (BIF) and Tuffs}

BIF and tuffs are abundant compared to all other lithological units of Geita Hills (Figure 2). BIF is composed of alternating layers of iron oxides and cherts of variable thickness from microscopic to macroscopic scales. Generally beds of tuffs occur at the bottom of $\mathrm{BIF} /$ chert layers and they become well exposed in road cuts at the bottom of ridges and hills (Figure 3(A)). Tuff occurs as whitish to reddish-brown deeply weathered thin to thick laminations (Figure 3(C)).

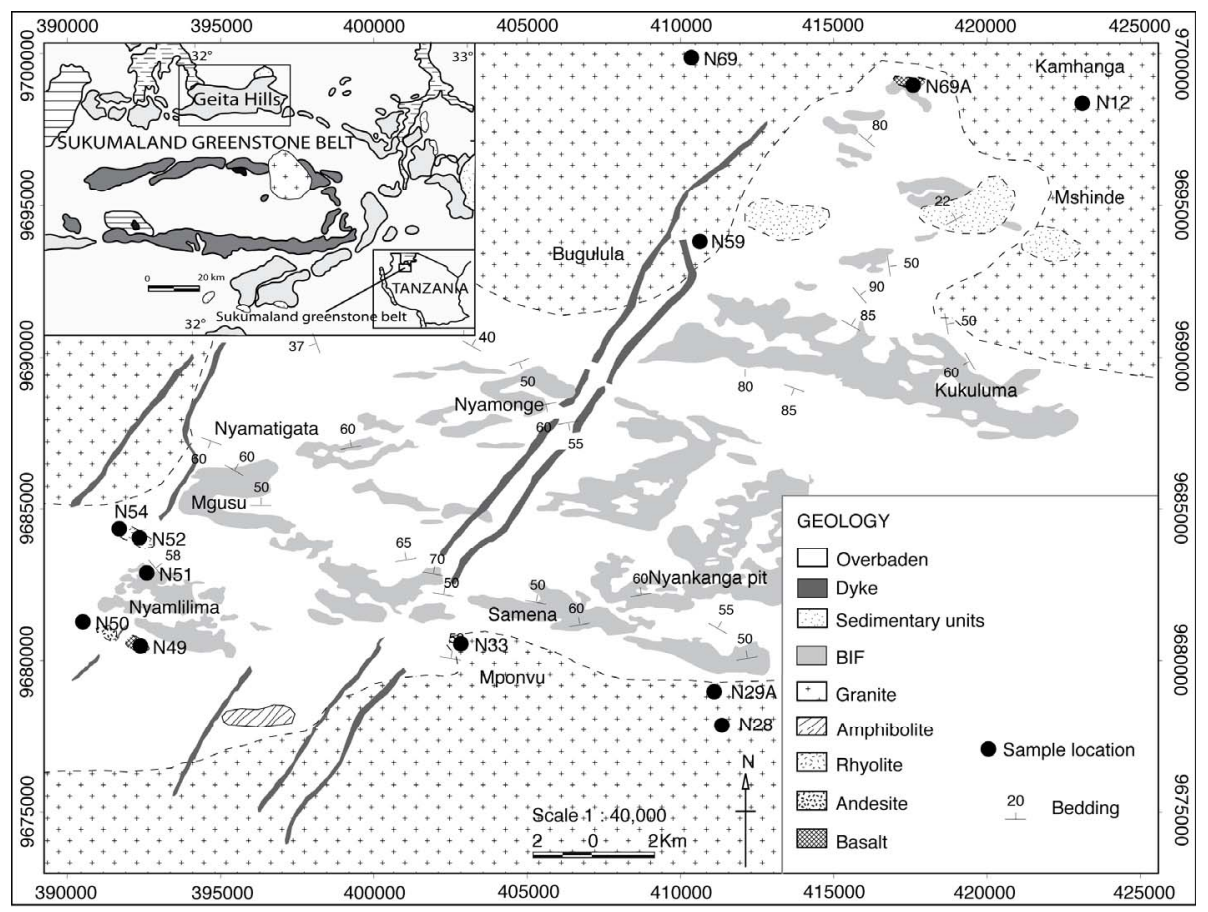

Figure 2. Geological map of Geita showing the distribution of major lithological units, sample locations and attitudes of bedding in Archean BIF/tuff units. The top left insert is a geological map of the Sukumaland Greenstone Belt indicating the location of Geita Hills (modified after [7]). 


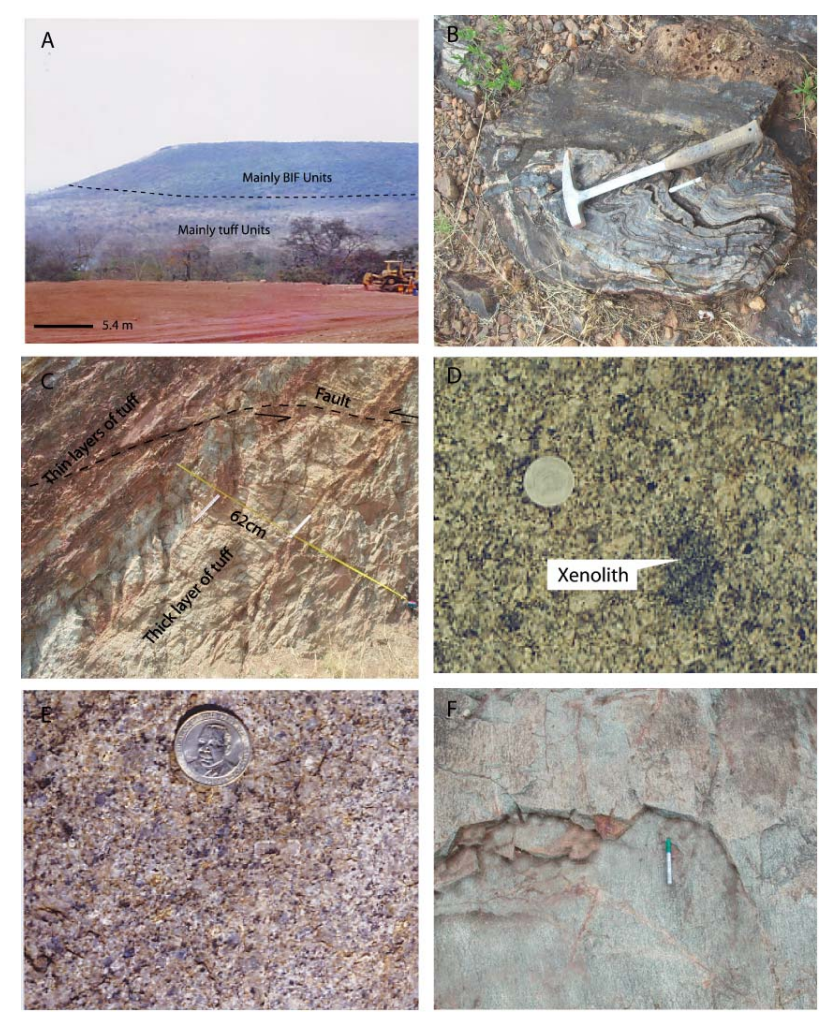

Figure 3. (A) Field occurrence of greenstones (BIFs and tuffs) at one of the Hills in Geita; (B) Polycline folds in BIFs; (C) Road exposure of the tuffs layers with variable thickness; (D) Massive, coarse-grained biotite granite with mafic xenolith, from northern Geita; (E) Massive alkali granite from the south of Geita, Bukoli pluton; (F) Biotite granodiorite with gneissic fabric, from Samena.

The BIF/chert layers are strongly folded to polycline folds (Figure 3(B)). Disharmonic polycline folding with respect to axial planes directions was observed in wellexposed BIF/chert layers. According to previous studies $[17,18]$ records of plunge of fold axes were generally at $350^{\circ} / 45^{\circ}$. Fold data from previous studies conform to our observations. Our pole plots of the bedding planes fall in a girdle which describes $050^{\circ} / 50^{\circ} / \mathrm{SE}$ great circle with a pole of $320^{\circ} / 40^{\circ}$ interpreted as the axis of a large-scale folds (Figure 4(A)). Major joint population attitudes from greenstones are $092^{\circ} / 85^{\circ} / \mathrm{N}$ or $\mathrm{S}, 337^{\circ} / 83 / \mathrm{ENE}$ or WSW and $010^{\circ} / 85 / \mathrm{ESE}$ or WNW, which are similar to those of granites (Figure 4(D)).

Measurements of shear zones and faults were taken in both greenstones and granites. Stereographic contour pole plots of shears and faults in the greenstones display three major populations. The major set of the populations has average attitudes of $100^{\circ} / 65 / \mathrm{NNE}$. The other two are conjugate faults with mean records of $010^{\circ} / 85^{\circ}$ dipping to WNW or ESE and $320^{\circ} / 82^{\circ}$ /dipping ENE or WSW (Figure 4(C)). The patterns of contour pole plots for shear zones and faults in granites yield similar patterns as those recorded in greenstones (Figure 4(C)). There are

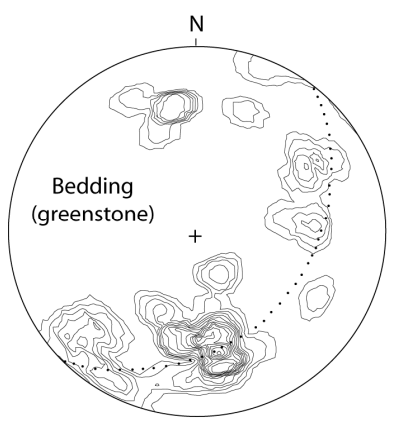

(A)

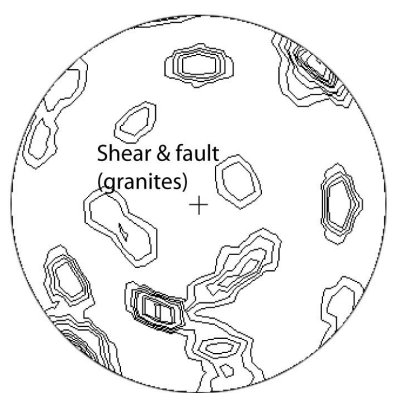

(C)

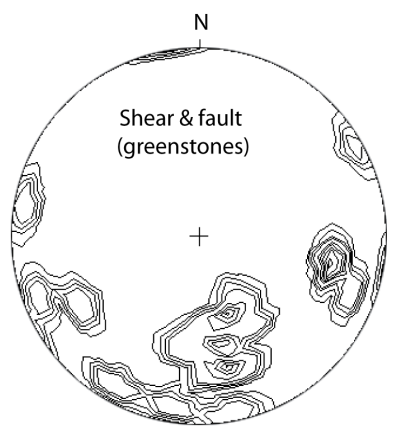

(B)

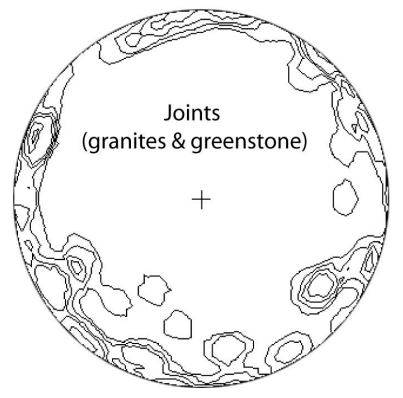

(D)
Figure 4. Stereographic contour of different rock types of Geita region. (A) Contour patterns of the poles of bedding planes; (B) Attitudes of shear and fault planes in greenstones; (C) Attitudes of shear and fault planes in granites; (D) Attitudes of joints in granites and greenstones.

three main sets. The $085^{\circ} / 50^{\circ} / \mathrm{NNW}$ is the main set whereas $315^{\circ} / 85^{\circ} / \mathrm{SW}$ or $\mathrm{NE}$ and $045 / 85 / \mathrm{NW}$ or SE are conjugate faults.

\subsubsection{Granites}

Different types of granites flank the Geita Archean supracrustal rocks in the north and in the south (Figure 2). Biotite-granodiorite and K-feldspar granites are very common. Biotite-granodiorite is the most dominant granitic unit in the area. The rock is locally strongly sheared attaining gneissic fabric with an attitude of $080^{\circ} / 70^{\circ}$ \% NNW (e.g. in the south of the Samena Hill, Figure 3(F)). The biotite-granodiorites in northern Geita are characterrized by large xenoliths of mafic composition (Figure 3(D)).

K-feldspar granite was found in the south and north of the supracrustal rocks. K-feldspar granite from Mpomvu is strongly sheared and the plane of shear is sub-vertical and trends in E-W direction. Massive outcrops of $\mathrm{K}$ feldspar granites were recorded from NNW of Mgusu and in the east of Bugulula (Figure 2) and it contains large euhedral randomly oriented and evenly distributed K-feldspar grains (Figure 3(E)).

\subsubsection{Volcanic Rocks}

Volcanic rocks are exposed in the north of the Nyam- 
lilima Hill (Figure 2). The rhyolite is very fine-grained whitish gray and moderately sheared. The shear zone is dextral with an attitude of $090^{\circ} / 85^{\circ} / \mathrm{N}$ and is filled with quartz veins. The rock is also cut by two prominent conjugate fault/joint systems with attitudes of $020^{\circ} / 75^{\circ} / \mathrm{NW}$ (sinistral) and $130^{\circ} / 85^{\circ} / \mathrm{NE}$ (dextral). Andesite is very fine-grained dark gray and sheared. It is exposed in the south of Nyamlilima (Figure 2). The shear zones in andesite has an average attitude of $060^{\circ} / 45^{\circ} / \mathrm{NW}$. Basalt occurs as patches in two localities south of Nyamlilima and in Kamhanga (Figure 2). Basalt exposed at Kamhanga is dark gray and massive whereas basalt exposed in the south of Nyamlilima is moderately sheared and the shear zones have an average attitude of $070^{\circ} / 45^{\circ} / \mathrm{NW}$ (Figure 2).

\subsubsection{Clastic Sedimentary Rocks}

Clastic sedimentary rocks are exposed in northern part of Geita (Figure 2). Outcrops of sandstone-greywacke, conglomerate, siltstone and mudstone-shale can be identified. These layers are found to alternate in some places. The average reading of the attitude of the beds is $085^{\circ} \%$ $45^{\circ} / \mathrm{NNW}$ and they are crosscut by randomly oriented joint systems.

\subsection{Metamorphism}

Petrographically, BIF samples are composed of recrystallized chert and magnetite together with typical greenschist facies metamorphic minerals of actinolite, epidote and chlorite. Calcite, titanite, ilmenite and biotite may also be present. Reference [14] reported a local contact metamorphism in BIF to belong to epidote-amphiboliteto amphibolite-facies with critical mineral assemblages of garnet-grunerite-epidote-quartz and garnet-ferrogedritebiotite-quartz.

The grade of metamorphism in granites is greenschist facies and the characteristic mineral assemblage found virtually in all granites is muscovite-epidote-chlorite. Calcite, titanite, ilmenite and sericite/phengite are only found in few samples.

Basalt is metamorphosed at greenschist facies with mineral assemblage of chlorite-epidote-actinolite. However, basalt is locally metamorphosed to amphibolite facies with mineral assemblage ferrohornblende-ferrotschermakite-plagioclase-quartz-epidote-titanite-ilmenite.

\subsection{Geochemistry}

\subsubsection{Major Elements}

Major elements composition of basalt, rhyolite and granites are presented in Table 1. Their $\mathrm{SiO}_{2}$ contents range between $45.84 \mathrm{wt} \%$ and $50.24 \mathrm{wt} \%$ in basalt, 63.34 wt $\%$ and $68.49 \mathrm{wt} \%$ in rhyolites, and $67.67 \mathrm{wt} \%$ and $76.55 \mathrm{wt} \%$ in granites. Major element triangular plot of
Irvine and Baragar (1971) $\left(\mathrm{Na}_{2} \mathrm{O}+\mathrm{K}_{2} \mathrm{O}, \mathrm{FeO}+\mathrm{TiO}_{2}\right.$, MgO: AFM diagram) indicates that the rhyolite and granites rock samples belongs to calc-alkaline series and the basalt in the tholeiitic series (Figure 5).

Geita granitic suites plot as granite and granodiorite in the classification diagram of [19,20] (Figure 6(a)) and as I-type granites (Figure 6(b)). The aluminium satura- tion index $\left[\mathrm{Al}_{2} \mathrm{O}_{3} /\left(\mathrm{CaO}+\mathrm{Na}_{2} \mathrm{O}+\mathrm{K}_{2} \mathrm{O}\right)\right]$ of these granitic rocks range between 1.33 and 1.68, and their molar $\mathrm{Al}_{2} \mathrm{O}_{3} /\left(\mathrm{Na}_{2} \mathrm{O}+\mathrm{K}_{2} \mathrm{O}\right)$ is higher than 1.0 (Table 1), indicating metaluminous character with one sample plotting in the peraluminous field [2] (Figure 6(c)). In the geotectonic discrimination diagram after [22], these rocks plot in the fields of syn-collision to late orogenic belts (Figure 6(d)).

\subsubsection{Rare Earth Elements (REEs)}

A total of six samples of basalt (1), rhyolites (2) and granites (3) were selected for trace and REEs studies and their compositions are presented in Table 2. The chondrite normalized REE pattern of the basalt sample is almost flat and show lower concentration than those of the average mid ocean ridge basalt (MORB) values indicating a slightly high degree of partial melting than the average normal MORB values (Figure 7(a)). This pattern is very much similar to that of enriched MORBs known as E-MORB $[25,26]$. The $(\mathrm{La} / \mathrm{Sm})_{\mathrm{N}}$ ratio indicates a slight enrichment at 1.11 and when this value is combined with $\mathrm{Nb} / \mathrm{La}$ values of 0.55 the rock plots in the field of back-arc basalts (Table 2 and Figure 8).

Rhyolites and granites display similar chondrite normalized REE patterns displaying strong enrichment in the light rare earth elements (LREEs) (Figure 7(b)). $(\mathrm{La} / \mathrm{Sm})_{\mathrm{N}}$ of ryholites range between 2.53 and 3.95 and that of granites range between 4.08 and 4.27 (Table 2), when the $(\mathrm{La} / \mathrm{Sm})_{\mathrm{N}}$ values are plotted together with the $\mathrm{Nb} / \mathrm{La}$ ratios granites and rhyolites show strong affinities to the magma source of the continental arc setting (Figure 8).

The ocean ridge granite (ORG) normalized geochemical

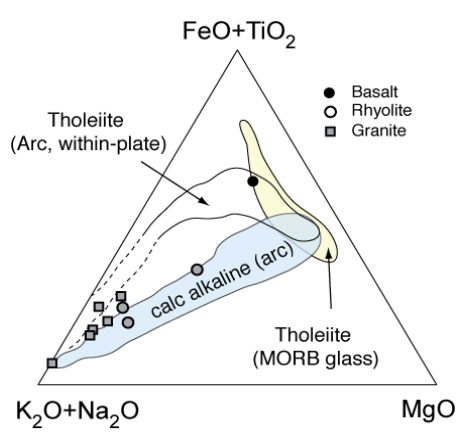

Figure 5. Discrimination diagram for calc-alkaline and tholeiite igneous rocks after [23]. 


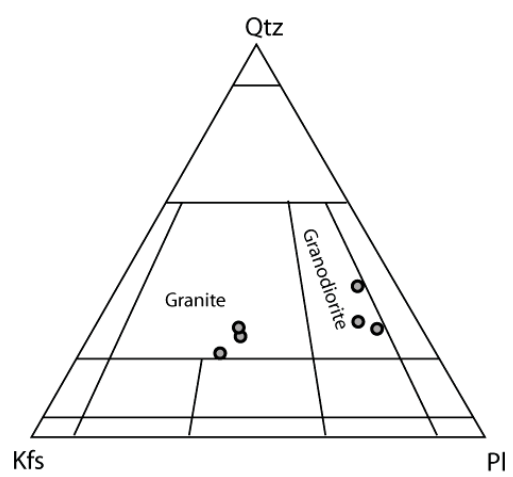

(a)

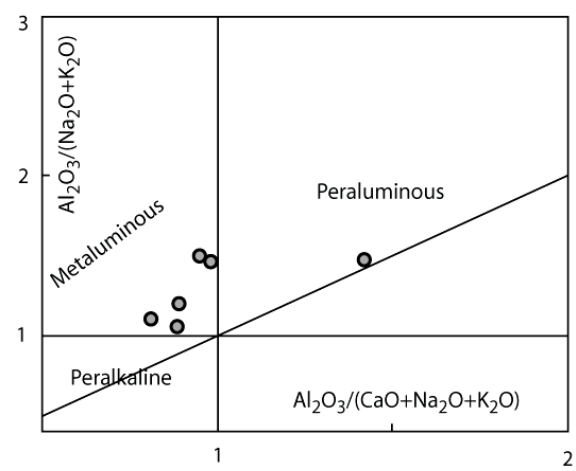

(c)

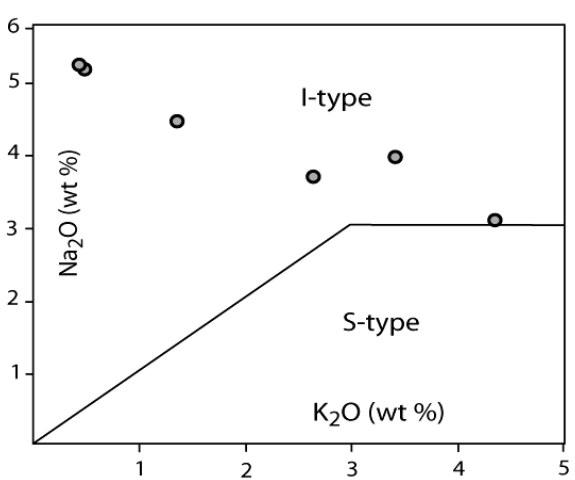

(b)

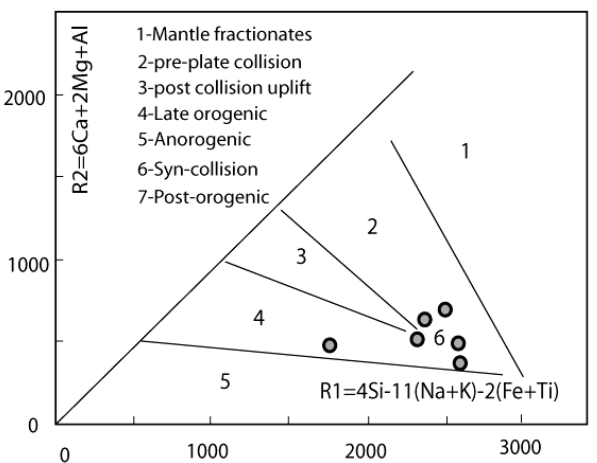

(d)

Figure 6. (a) Granitic classification diagrams after [19], Geita granites are classified as granites and granodiorites; (b) Discrimination diagram for I and S-type granites, after [24]. Geita granitoids plot in the I-type field; (c) $\mathrm{Al}_{2} \mathrm{O}_{3} /\left(\mathrm{Na}_{2} \mathrm{O}+\mathrm{K}_{2} \mathrm{O}\right)$ vs $\mathrm{Al}_{2} \mathrm{O}_{3} /\left(\mathrm{CaO}+\mathrm{Na}_{2} \mathrm{O}+\right.$ $\mathrm{K}_{2} \mathrm{O}$ ) diagram after [21] note: Geita granites are plotting in metaluminous field and one sample is plotting in peraluminous field; (d) Tectonic settings discrimination diagram after [22]. Note: the Geita granitoids plot in the syn-collision and late orogenic fields.

Table 1. Major element composition (in wt\%) of Geita Hills volcanics and granitoids.

\begin{tabular}{|c|c|c|c|c|c|c|c|c|c|c|c|c|c|c|}
\hline \multirow{3}{*}{ Sample } & \multicolumn{2}{|c|}{ Basalt } & \multicolumn{4}{|c|}{ Rhyolite } & \multicolumn{2}{|c|}{ Granite } & \multirow[b]{2}{*}{ N29A } & \multirow[b]{2}{*}{ N33 } & \multirow[b]{2}{*}{ N59 } & \multirow[b]{2}{*}{ N69 } & \multicolumn{2}{|c|}{ International Standard } \\
\hline & N49 & N50 & N69A & N51 & N52 & N54 & N12 & N28 & & & & & BHVO-2 & BHVO-2 \\
\hline & & & & & & & & & & & & & Literature & Duplicate \\
\hline $\mathrm{SiO}_{2}$ & 50.24 & 52.18 & 45.84 & 68.34 & 63.52 & 68.49 & 70.54 & 71.77 & 70.83 & 67.67 & 76.55 & 71.30 & 49.88 & 49.71 \\
\hline $\mathrm{TiO}_{2}$ & 1.19 & 1.17 & 0.68 & 0.26 & 0.63 & 0.65 & 0.28 & 0.23 & 0.22 & 0.29 & 0.04 & 0.44 & 2.79 & 2.77 \\
\hline $\mathrm{Al}_{2} \mathrm{O}_{3}$ & 14.79 & 14.60 & 10.99 & 15.34 & 15.82 & 15.95 & 14.13 & 15.45 & 15.60 & 14.63 & 12.78 & 13.32 & 13.63 & 13.57 \\
\hline $\mathrm{FeO}$ & 12.30 & 11.56 & 20.13 & 2.64 & 4.64 & 1.74 & 2.03 & 1.42 & 1.47 & 2.84 & 0.64 & 2.79 & 12.16 & 12.14 \\
\hline $\mathrm{MnO}$ & 0.18 & 0.19 & 0.63 & 0.06 & 0.11 & 0.06 & 0.04 & 0.03 & 0.02 & 0.07 & 0.04 & 0.05 & 0.17 & 0.17 \\
\hline $\mathrm{MgO}$ & 4.63 & 3.68 & 6.18 & 1.16 & 3.13 & 1.23 & 0.79 & 0.55 & 0.51 & 0.94 & 0.10 & 0.47 & 6.98 & 6.89 \\
\hline $\mathrm{CaO}$ & 12.06 & 12.85 & 12.42 & 2.69 & 5.26 & 4.93 & 2.24 & 2.37 & 2.62 & 3.39 & 0.31 & 1.50 & 11.56 & 11.51 \\
\hline $\mathrm{Na}_{2} \mathrm{O}$ & 2.67 & 2.02 & 0.96 & 3.40 & 4.77 & 4.38 & 3.75 & 5.35 & 5.27 & 4.52 & 4.05 & 3.15 & 2.62 & 2.59 \\
\hline $\mathrm{K}_{2} \mathrm{O}$ & 0.33 & 0.13 & 0.51 & 3.83 & 0.78 & 1.72 & 3.63 & 1.45 & 1.48 & 2.36 & 4.42 & 5.34 & 0.53 & 0.53 \\
\hline $\mathrm{P}_{2} \mathrm{O}_{5}$ & 0.09 & 0.09 & 0.05 & 0.13 & 0.16 & 0.17 & 0.08 & 0.08 & 0.07 & 0.16 & 0.02 & 0.12 & 0.28 & 0.28 \\
\hline LOI & 0.82 & 1.16 & 1.02 & 1.41 & 1.30 & 0.93 & 0.85 & 0.89 & 0.90 & 2.33 & 0.52 & 0.80 & 0.00 & 0.00 \\
\hline Total & 99.30 & 99.63 & 99.41 & 99.26 & 100.12 & 100.25 & 98.36 & 99.59 & 98.99 & 99.20 & 99.47 & 99.28 & 100.60 & 100.60 \\
\hline
\end{tabular}

LOI = Loss on ignition. 
Table 2. Trace element composition (in ppm) of Geita Hills volcanics and granitoids.

\begin{tabular}{|c|c|c|c|c|c|c|c|c|}
\hline \multirow{3}{*}{ Sample } & \multirow{2}{*}{$\begin{array}{c}\text { Basalt } \\
\text { N49 }\end{array}$} & \multicolumn{2}{|c|}{ Rhyolite } & \multicolumn{2}{|c|}{ Granite } & \multirow[b]{2}{*}{ N29A } & \multicolumn{2}{|c|}{ International Standard } \\
\hline & & N51 & N54 & N12 & N33 & & BHVO-2 & BHVO-2 \\
\hline & & & & & & & Literature & Duplicate \\
\hline $\mathrm{V}$ & 341 & 41 & 88 & 31.1 & 52.7 & 23.0 & 332 & 302 \\
\hline $\mathrm{Cr}$ & 120 & 38 & 153 & 36.4 & 10.3 & 3.84 & 363 & 363 \\
\hline Co & 48.9 & 5.7 & 20.4 & 5.41 & 6.29 & 3.76 & 46.3 & 43.0 \\
\hline $\mathrm{Zn}$ & 131 & 55 & 47 & 44.8 & 80.4 & 44.0 & 112 & 105 \\
\hline $\mathrm{Ga}$ & 19.4 & 21.1 & 19.8 & 19.8 & 24.6 & 21.1 & 22.5 & 21.9 \\
\hline $\mathrm{Rb}$ & 8.06 & 114 & 32.07 & 124 & 64.3 & 51.6 & 9.39 & 8.96 \\
\hline $\mathrm{Sr}$ & 147 & 713 & 407 & 281 & 1436 & 686 & 405 & 385 \\
\hline $\mathrm{Y}$ & 27.3 & 10.3 & 14.2 & 11.6 & 16.4 & 3.4 & 26.3 & 25.6 \\
\hline $\mathrm{Zr}$ & 71.0 & 122 & 149 & 138 & 192 & 111 & 176.6 & 165.6 \\
\hline $\mathrm{Nb}$ & 2.79 & 4.72 & 4.17 & 6.59 & 8.47 & 0.90 & 17.79 & 16.94 \\
\hline Cs & 0.58 & 1.64 & 1.86 & 4.23 & 3.12 & 3.60 & 0.10 & 0.10 \\
\hline $\mathrm{La}$ & 5.04 & 27.0 & 15.4 & 32.1 & 49.1 & 7.55 & 15.08 & 14.58 \\
\hline $\mathrm{Ce}$ & 10.9 & 50.6 & 32.1 & 59.1 & 95.8 & 11.0 & 37.2 & 35.5 \\
\hline $\operatorname{Pr}$ & 1.77 & 6.05 & 4.19 & 6.43 & 11.4 & 1.40 & 5.29 & 5.07 \\
\hline $\mathrm{Nd}$ & 9.17 & 24.1 & 18.4 & 23.2 & 45.1 & 5.36 & 24.23 & 23.32 \\
\hline $\mathrm{Sm}$ & 2.85 & 4.30 & 3.82 & 3.83 & 7.57 & 0.88 & 5.97 & 5.80 \\
\hline $\mathrm{Eu}$ & 0.97 & 0.84 & 0.99 & 0.65 & 1.57 & 0.33 & 2.03 & 1.96 \\
\hline Gd & 3.94 & 2.74 & 3.25 & 2.86 & 4.78 & 0.92 & 6.26 & 5.98 \\
\hline Dy & 4.86 & 1.91 & 2.60 & 2.12 & 2.98 & 0.50 & 5.26 & 5.09 \\
\hline Но & 1.01 & 0.35 & 0.50 & 0.37 & 0.54 & 0.07 & 0.97 & 0.93 \\
\hline Er & 2.60 & 0.82 & 1.14 & 0.88 & 1.20 & 0.18 & 2.40 & 2.31 \\
\hline $\mathrm{Tm}$ & 0.41 & 0.12 & 0.18 & 0.14 & 0.17 & 0.02 & 0.32 & 0.31 \\
\hline $\mathrm{Yb}$ & 2.91 & 0.95 & 1.31 & 1.11 & 1.33 & 0.40 & 1.98 & 1.90 \\
\hline $\mathrm{Lu}$ & 0.43 & 0.14 & 0.19 & 0.16 & 0.19 & 0.03 & 0.28 & 0.27 \\
\hline $\mathrm{Hf}$ & 2.21 & 3.83 & 4.17 & 4.31 & 5.24 & 3.16 & 4.41 & 4.29 \\
\hline Та & 0.26 & 0.44 & 0.48 & 0.83 & 0.75 & 0.09 & 1.12 & 1.07 \\
\hline Th & 0.33 & 7.16 & 3.15 & 19.2 & 16.1 & 0.85 & 1.23 & 1.18 \\
\hline $\mathrm{U}$ & 0.06 & 2.99 & 0.79 & 7.00 & 7.01 & 0.58 & 0.42 & 0.40 \\
\hline \multicolumn{9}{|l|}{ Ratios } \\
\hline $\mathrm{Nb} / \mathrm{La}$ & 0.55 & 0.17 & 0.27 & 0.21 & 0.17 & 0.12 & & \\
\hline$(\mathrm{La} / \mathrm{Sm})_{\mathrm{N}}$ & 1.11 & 3.95 & 2.53 & 5.27 & 4.08 & 5.40 & & \\
\hline
\end{tabular}

pattern for granite samples N12, N33 and N29A display the typical pattern for volcanic arc granites (Figure 7(c)). All the samples have strong positive anomalies of $\mathrm{K}, \mathrm{Rb}$ and $\mathrm{Ba}$ whereas the $\mathrm{Y}$ and $\mathrm{Yb}$ display strong negative anomaly. It has been shown by [28] that like volcanic arc basalts, the calc-alkaline volcanic arc granites are characterized by enrichments of $\mathrm{K}, \mathrm{Rb}, \mathrm{B}$ and Th relative to other trace elements, and that $\mathrm{Ce}$ and $\mathrm{Sm}$ are elevated 


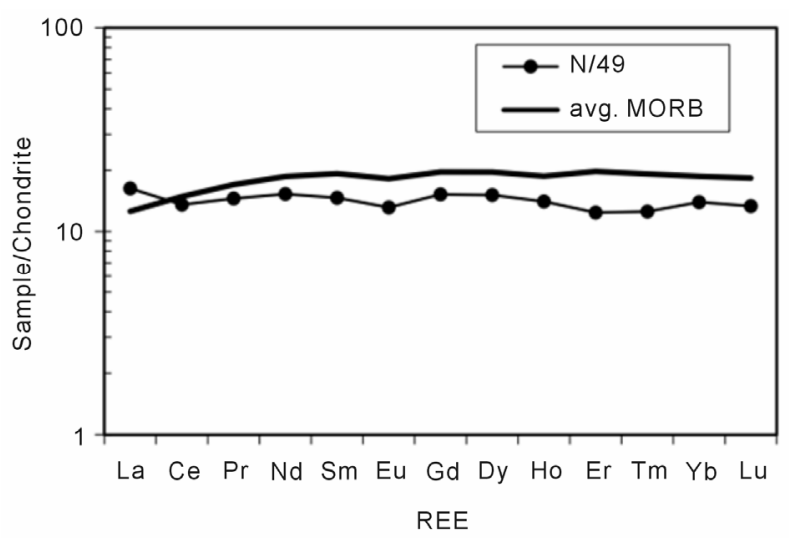

(a)

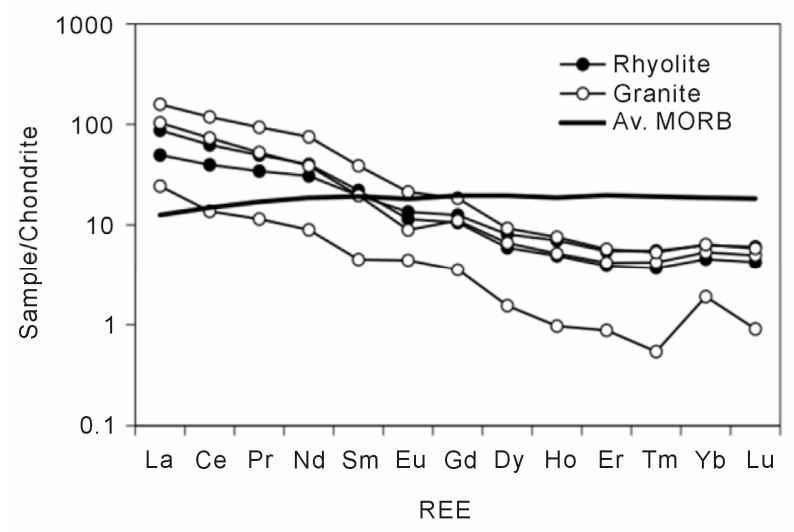

(b)

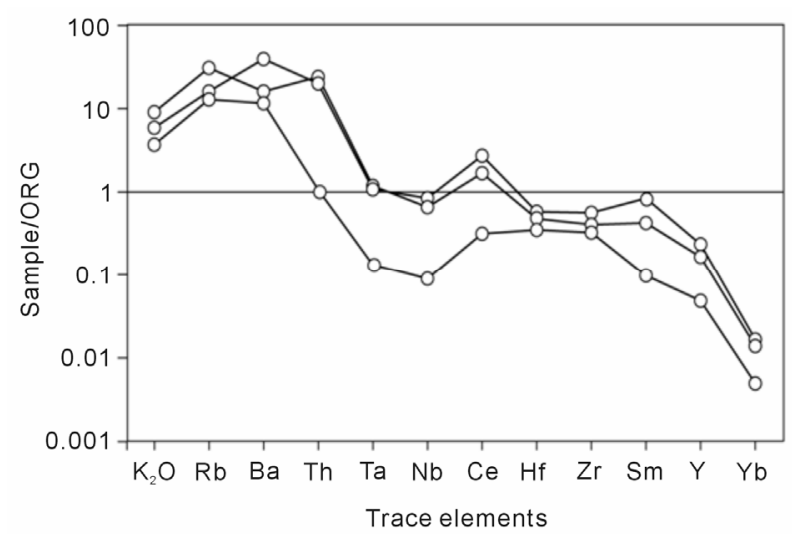

(c)

Figure 7. (a) and (b) Chondrite-normalized REE pattern of basalt, rhyolite and granite samples, normalizing values from [27]; (c) Ocean ridge granite (ORG) normalized geochemical patterns for granites, normalizing values from [28].

when compared to Ta, Nb, Hf, Zr, Y and Yb levels. A further significant feature is the low value of $\mathrm{Y}$ and $\mathrm{Yb}$ relative to the normalizing composition. The trace elements patterns for the representative granites are very similar suggesting that they have been formed in the same tectonic environment. These observations suggest that these granites have volcanic arc affinities particularly the

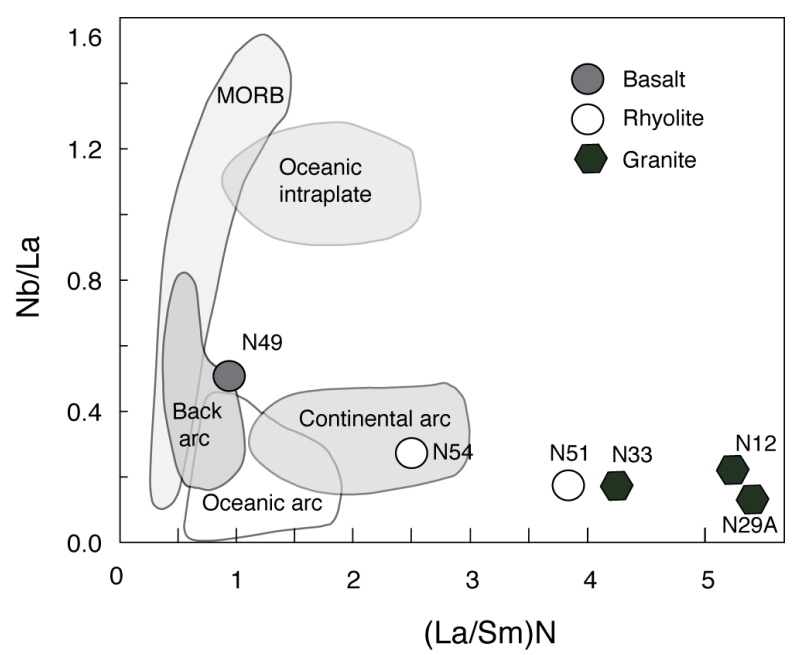

Figure 8. $\mathrm{Nb} / \mathrm{La}$ vs $(\mathrm{La} / \mathrm{Sm})_{\mathrm{N}}$ diagram after [29], showing the tectonic setting of Geita Hills basalt (back arc), rhyolites and granites (continental arc).

continental arc.

\section{CONCLUSIONS}

The Archean BIFs and tuffs dominate the Geita Hills. These two dominant units are caped by patches of Kavirondian clastic sediments that include shale-mudstone, greywacke-sandstone, and conglomerate. The bottom is characterized by rarely cropping out volcanic rocks (basalts, andesites and rhyolites). Deformed and undeformed granitoids of variable mineral and chemical composition flank the volcano-sedimentary sequence of Geita Hills and gabbroic to granitic dikes crosscut and intrude the greenstone rocks.

Attitudes of bedding planes in BIFs, tuffs and clastic sediments fall in a girdle that describes $050^{\circ} / 50^{\circ} / \mathrm{SE}$ great circle with a pole of $320^{\circ} / 40^{\circ}$ interpreted as a fold axis of a large-scale folding of the greenstone. Faults, joints and local shear are common in all rock units.

Rocks of Geita Hills consist of low-grade metamorphic mineral assemblages that belong to greenschist facies. However, locally the BIFs and basalts are metamorphosed to epidote-amphibolite to amphibolite facies.

Basalt belongs to tholeiite series whereas granite, granodiorites and rhyolites belong to calc-alkaline series. The E-MORB rare earth element signature of the basalt suggests a remnant of an Archean ocean. The I-type synorogenic metaluminous granite-granodiorite association have rare earth element composition with volcanic arc affinities. Geochemical signatures of granitoids and basalt suggest that the Geita Hills basalts erupted in an oceanic ridge setting and the granites rhyolites in a volcanic arc setting particularly the continental arc. This association means that the Geita Hills volcanic rocks and granites represent relics of the Archean back-arc and 
continental arc rock assemblages.

\section{ACKNOWLEDGEMENTS}

Sida/SAREC funded the fieldwork under the program Research Capacity Development at the Geology Department, University of Dar es Salaam and DAAD sponsored a short visit to Germany. We wish to express our sincere gratitude to Prof. Dr. Volker Schenk for allowing all the analyses and petrographic studies to be conducted in the laboratories at the University of Kiel and Dr. Peter Appel for mineral chemistry analyses, Mr. John Hill of Geita Gold Mine for his logistical support in the field at Geita Gold Mine. Other geologists who provided invaluable help in the field include Mr. Gerald Chuwa, Mr. Mayala Nkuli and Mr. Charles Mguto.

\section{REFERENCES}

[1] Condie, K.C. (1981) Archaean greenstone belts. Amsterdam, Elsevier, 434 p.

[2] Condie, K.C. (1989) Geochemical changes in basalts and andesites across the Archean-Proterozoic boundary: Identification and significance. Lithos, 23, 1-18. doi:10.1016/0024-4937(89)90020-0

[3] Fraser, I.A. and Heywood, W.W. (1978) Metamorphism in the Canadian shield. Geological Survey of Canada paper, 10-78. doi:10.4095/133909

[4] Barth, H. (1990) Provisional geological map of lake Victoria gold field, Tanzania. Schweizer Mineralogische und Petrographische Mitteilungen, 43, 127-137.

[5] Borg, G. and Krogh, T. (1999) Isotopic age data of single zircon from the Archaean Sukumaland Greenstone Belt. Tanzania. Journal of African Earth Sciences, 29, 301-312. doi:10.1016/S0899-5362(99)00099-8

[6] Manya, S. and Maboko, M.A.H. (2003) Dating basaltic volcanism in the Neoarchaean Sukumaland Greenstone Belt of the Tanzania Craton using the Sm-Nd method: Implications for the geological evolution of the Tanzania Craton. Precambrian Research, 121, 35-45. doi:10.1016/S0301-9268(02)00195-X

[7] Borg, G., and Shackleton, R.M. (1997) The Tanzania and NE Zaire Craton. In: de Wit, M.J. and Ashwal, L.D., Eds., Greenstone Belts, Clarendon Press Oxford, 608-619.

[8] Bell, K. and Dodson, M.H. (1981) The geochronology of the Tanzania shield. Journal of Geology, 89, 109-229. doi:10.1086/628567

[9] Borg, G. (1992) New aspects on the lithostratigraphy and evolution of Siga hills, an Archaean granite-Greenstone terrain in NW-Tanzania. Zeitschrift Angrewandte Geologie, 38, 89-93.

[10] Windley, B.F. (1995) The evolving continents. 3rd Edition, John Wiley and Sons, New York.

[11] Borg, G. (1994) The Geita Gold deposit in NW Tanzania. Geology, Ore petrology, Geochemistry and timing of events. Geologische Jahrbuch, 100, 545-595.

[12] Rammlmair, D., Höhndorf, A., Borg, G. and Hiza, G.N. (1990) Nouvelles Datations Isotopiques des granites et des gabbros de la Region "greenstone" Granitique du Sukumaland, N.W. Tanzanie. 15th Colloquium African Geology (Abstract Volume), Nancy.

[13] Quennel, A.M., McKinley, A.C.M. and Aitken, W.G. (1956) Summary of the geology of Tanganyika Memoir I, Part II: Introduction and Stratigraphy. Government Printer, Dar es Salaam.

[14] Boniface, N. (2011) Contact metamorphism in the supracrustal rocks of the Sukumaland Greenstone Belt in the North West Tanzania. Tanzania Journal of Sciences, 37, 144-155.

[15] Gabe-Schönberg, C.D. (1993) Simultaneous determination of thirty seven trace elements in twenty-eight international rock standards by ICP-MS. Geostandards Newsletter, 17, 81-97. doi:10.1111/j.1751-908X.1993.tb00122.x

[16] Mruma, A.H. (2009) Multi-structures of a single deformation phase in the Sukumaland Greenstone Belt. Tanzania Journal of Earth Sciences, 1, 75-86.

[17] Borg, G. (1993) Epigenetic, BIF-hosted Au mineralization at Geita, Tanzania, Evidence from structural geology. Ore petrography and geochemistry. In: Hach-Ali, F., TorresRuiz and Gervilla, Eds., Current Research in Geology Applied to Ore Deposit, Granada, 415-418.

[18] McGrath, A. (1999) Structural and lithological controls on gold mineralization in the Geita Gold mine, Northern Tanzania. Masters Thesis, University of Leicester, United Kingdom.

[19] Le Maitre, R.W., Bateman, P., Dudeka, A., Keller, J., Lameyre Le Bas, M.J., Sabine, P.A., Schimid, R., Sorensen, H., Streckeisen, A., Woolley, A.R. and Zannettin, B. (1989) A classification of igneous rocks and glossary of items. Blackwell, Oxford.

[20] O’Connor, J.T. (1965) A classification of quartz rich igneous rock based on feldspar ratios. US Geological Survey, 525B, B79-B84.

[21] Maniard, P.D. and Piccoli, P.M. (1989) Tectonic discrimination of granitoids. Geological society of America bulletin, 101, 635-643. doi:10.1130/0016-7606(1989)101<0635:TDOG>2.3.CO; $\underline{2}$

[22] Batchelor, R.A. and Bowden, P. (1985) Petrogenetic interpretation of granitoid rock series using multcationic parameters. Chemical Geology, 48, 43-55. doi:10.1016/0009-2541(85)90034-8

[23] Irvine, T.N. and Baragar W.R.A. (1971) A guide to the chemical classification of the common volcanic rocks. Canadian Journal of Earth Sciences, 8, 523-548. doi:10.1139/e71-055

[24] Chapell, B.W. and White, A.J.R. (1984) I and S type granites in the Lachlan Fold Belt, Southeastern Australia. In: Kequin, X. and Guanchi, T., Eds., Geology of Granite and Their Metallogenic Relations, Beijing Science Press, 87-101.

[25] Schilling, J.G., Zajac, M., Evans, R., Johnston, T., White, W., Devine, J.D. and Kingsley, R. (1983) Petrologic and geochemical variations along the Mid-Atlantic Ridge from 29 degrees $\mathrm{N}$ to 73 degrees N. American Journal of 
Science, 238, 510-586. doi:10.2475/ajs.283.6.510

[26] Arevalo, R. Jr. and McDonough, W.F. (2010) Chemical variations and regional diversity observed in MORB. Chemical Geology, 271, 70-85. doi:10.1016/j.chemgeo.2009.12.013

[27] Boynton, W.V. (984) Cosmochemistry of the rare earth elements: Meteorite studies. In: Henderson, P., Ed., Rare Earth Element Geochemistry, Amsterdam, Elsevier, 63114.

[28] Harris, N.B.W., Pearce, J.A. and Tindle, A.G. (1984)
Trace element discrimination diagrams for the tectonic interpretation of granitic rocks. Journal of Petrology, 25, 956-983.

[29] John, T., Schenk, V., Haase, K., Scherer, E. and Tembo, F. (2003) Evidence for a Neoproterozoic ocean in southcentral Africa from mid-oceanic-ridge-type geochemical signatures and pressure-temperature estimates of Zambian eclogites. Geology, 31, 243-246.

doi:10.1130/0091-7613(2003)031<0243:EFANOI >2.0.C $\underline{\mathrm{O} ; 2}$ 